\title{
MODIFICATION OF THE QFD METHOD FOR DETERMINING NEWSPAPER CHARACTERISTICS
}

\author{
Diana Milčić, Jakov Borković, Adisa Vučina
}

Original scientific paper

Development of technology and new media affects the newspaper industry so that it results in decline of newspaper publication circulation. Suitable methods and tools to improve quality management system have been looked for to ensure sustainability and reduce the costs in newspaper production. Well-known systems of quality management such as ISO 9001, TQM, Lean manufacturing and QFD methods - Quality Function Deployment, are ubiquitous in production systems around the world. Each production system, including the system of newspaper production must meet the customer's requirements and all other value chain participants by recognizing the newspaper product properties. Although the QFD method is mainly used for developing a new product, this paper explores the possibility of its implementation in the newspaper production. It affects the improvement of the production process by acting preventively to detect compatibility. By examining the effects of certain tools in certain segments of the newspaper production system and their adaptation, a new method was developed - modified QFD, tested in the newspaper printing houses the research was conducted in. The method can be implemented in the newspaper production systems and thus make production processes more efficient and ensure sustainable business.

Keywords: QFD method, newspaper product characteristics, evaluation of the newspaper production quality system

\section{Modifikacija OFD metode za utvrđivanje karakteristika novinskog proizvoda}

Izvorni znanstveni članak Razvoj tehnologije i novih medija izravno utječe na novinsku industriju i rezultira padom naklada novinskih izdanja. Kako bi se osigurala održivost te smanjili troškovi u novinskoj proizvodnji pristupa se traženju pogodnih metoda i alata za unapređenje sustava upravljanja kvalitetom. Poznati sustavi upravljanja kvalitetom poput ISO 9001, TQM, Lean proizvodni koncept, te QFD metoda - evaluacija funkcije kvalitete sveprisutni su u različitim proizvodnim sustavima. Svaki proizvodni sustav, pa tako i proizvodni sustav novina mora zadovoljiti potrebe kupca ali i svih drugih zainteresiranih dionika - zaposlenika, vlasnika, dobavljača itd. Iako se QFD metoda uglavnom koristi za razvoj novog proizvoda, u radu se istražuje mogućnost primjene u novinskoj proizvodnji. Ispitivanjem efekata pojedinih alata u pojedinim segmentima sustava novinske proizvodnje i njihovom prilagodbom, razvijena je nova metoda - modificirana QFD testirana u novinskim tiskarama u kojima je provedeno istraživanje. Metoda se može primijeniti u novinskim tiskarama koje će na taj način proizvodne procese učiniti učinkovitijim i osigurati održivo poslovanje.

Ključneriječi: QFD metoda, karakteristike novinskog proizvoda, evaluacija sustava upravljanja kvalitetom

\section{Introduction}

Newspapers are a dynamic medium, and the method of their production has been constantly changing with the development of technology. There are more and more electronic alternatives for displaying news along with printed newspapers that have existed for centuries. In addition to changes in decline of newspaper publication circulation, new requirements for quality, scope, cost and distribution have significantly increased. The analysis of trends is essential for the newspaper industry in order to survive, adjust and improve efficiency in the long term. The challenges in the market focus attention on management change and cost reduction [1]. The need arose to develop processes and procedures allowing companies or project teams to gain knowledge about customer requirements and satisfaction, which would serve as a base for developing product and adapt and improve business processes. It is also necessary to implement business models that give emphasis to the important performances of existing processes, and not only to improve and introduce new technologies.

The analysis of theory and current research showed the lack of a comprehensive approach to quality management in newspaper production associated with improvements in the organization of newspaper production system based on the customer requirements [2]. Competitiveness of the newspaper production can only be achieved by changing organization of the business processor introducing new technologies. From the aspect of quality management, following the implementation of selected methods and tools to improve the quality, it is clear that, in order to achieve greater excellence, the way of thinking about quality improvement should be changed and it should be approached in a completely different way.

QFD-method is a modern method and its tools and principles will, according to the experiences from international practice, meet quality requirements and contribute to quality improvement. It is associated with product creation and production process consistent with customer requirements. Given the specificities of newspaper production, it was necessary to create a model that will fully control the quality in order to apply certain principles of known quality management systems in all phases of newspaper product creation and newspaper production process. QFD method was tested in practice [3] and showed potential to improve the process and consequently increase efficiency in the newspaper production.

\section{QFD method and newspaper industry, research methodology}

In the newspaper industry the QFD has been used to compare the characteristics and elements of quality in competitive publications, [4] in which the most important parameters were identified in contact with customers. In this paper the QFD method is used to link customer requirements with the newspaper products properties 
which indirectly affect the newspaper production. It was found that the inclusion of customers in product development and design increase its success in the market [5]. The impact of the customer wishes in various stages of new product development was analysed. The customer interaction was shown at the early stage in generating ideas and concept of product development and at the late stage as a prototype for testing the market. Such interaction had positive effects on the success of a new product or on the development of the existing one. A set of methods that can be used to collect data on customer requirements so that they contribute to technical properties of the newspaper product quality already exists. However, there is a structured procedure, confirmed in practice, that shows how to use this method in the newspaper industry, or how the customer requirements can be transferred into the critical functional characteristics of a quality newspaper product, leading indirectly to the reorganizing newspaper production, its production processes and sub-processes to the competitive level capable of surviving in the market. QFD method tools are applied throughout the whole course of process and sub-processes in newspaper production.

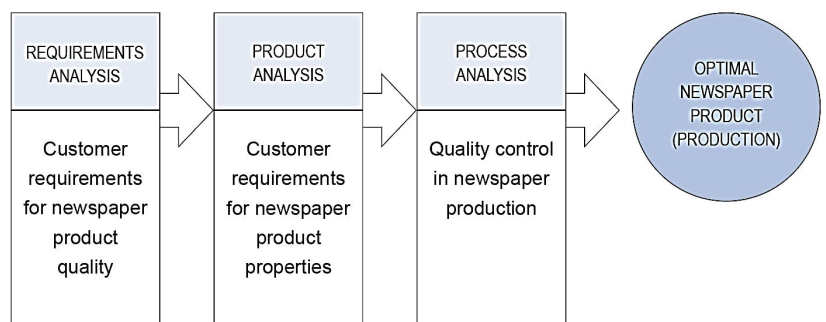

Figure 1 Development process in the newspaper production (Quality space of the magazine) [6]

In this paper the QFD method is used to link customer requirements with newspaper product properties indirectly affecting the creation of newspaper production. The idea of linking the QFD matrix is presented in Fig. 2 and it corresponds to the different participants in the product creation.

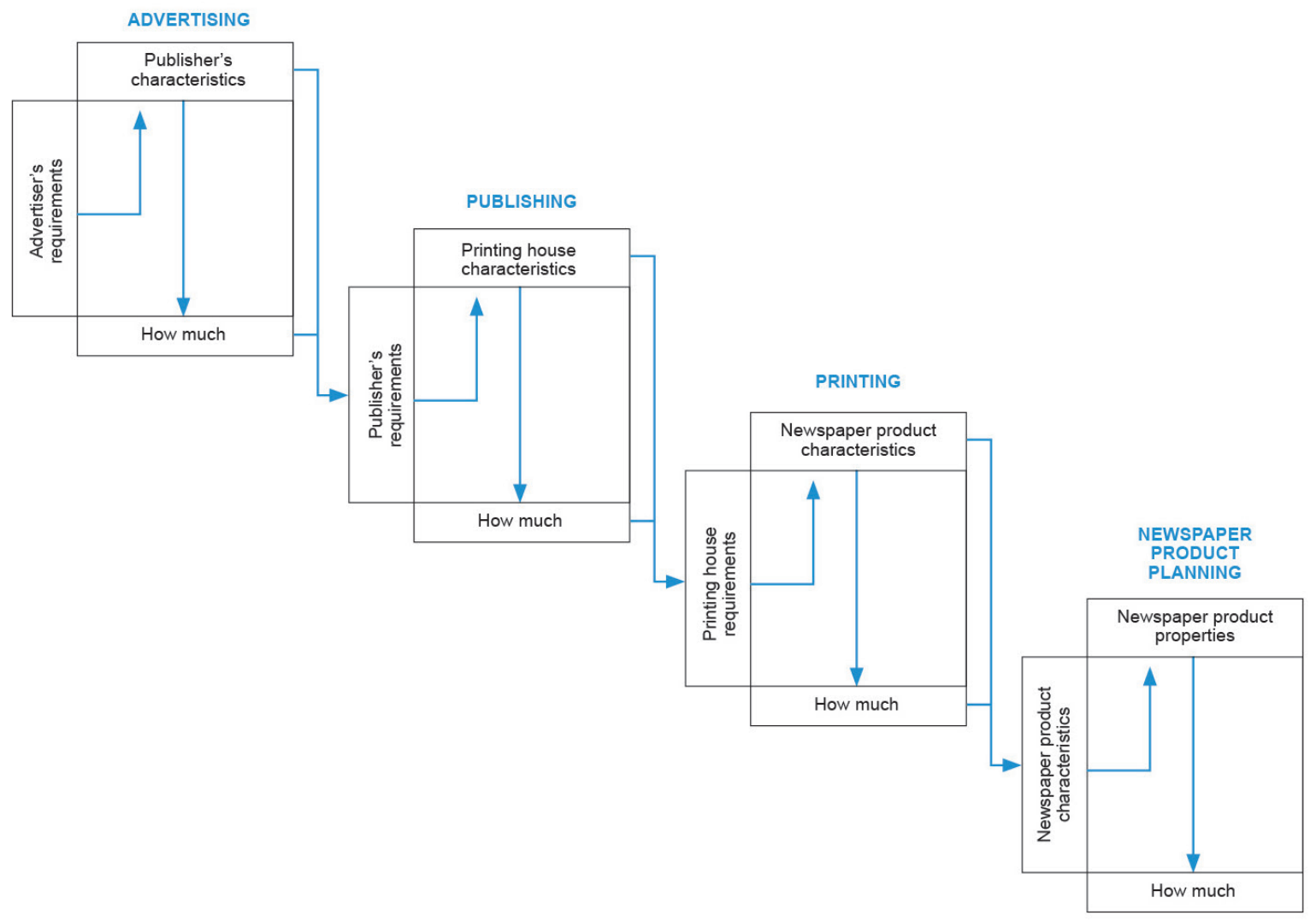

Figure 2 Four phases of the QFD in defining newspaper products quality characteristics

Generalization of data relevant to this research is the result of theoretical investigation and observation. An assessment was based on data on newspaper publishing, qualitative characteristics of the newspaper products and advertising industry $[7 \div 9]$.

Consequently, a survey and partly an interview were conducted in the selected five newspaper publishing houses related to the requirements of the advertisers, publishers and newspaper printing houses from the perspective of features and characteristics of the newspaper products. Detected characteristics and requirements were incorporated in modified QFD tables pursuant to the QFD methodology in accordance with this study. The correlations between customer requirements and newspaper production were analysed using QFD separately at each stage of defining quality, so that the requirements at different stages of creating a newspaper product could be identified (Fig. 2).

Each product can be identified and observed according to three aspects, strongly interdependent, namely physical, service and symbolic [10]. A newspaper product is a typical example of a product that combines physical, service and symbolic aspects. The final physical product includes layout, text, pictures and paper of the 
newspaper product. The special effects in advertising are also included in the physical product. The content of the service aspect varies in different parts of a newspaper product, from the publisher or advertiser services or services related to printing. The symbolic part, on the other hand, includes the target group, the definition of the target group, the positioning in the target group and information on how the target group uses a newspaper product. In this study, one of the goals is to clarify the roles of the service and symbolic aspects on customer satisfaction, as well as the role of the newspaper product quality in creating symbolic and service aspects in particular those related to the improvements in the newspaper production processes.

\section{Measurement and results}

\subsection{Customer requirements and expectations in the process of the newspaper product development}

The process of the product generic development arising from the identification of customer requirements by moving to the technical requirements takes place in four steps [11]:

1) Identifying the value chain of the end product. The requirement analysis is a tool to gain greater understanding of customer needs

2) Identifying the critical properties of the product throughout the value chain starting with the requirements of the value chain representatives: customer, advertiser, publisher and newspaper production

3) Finding association between customers, expected newspaper product quality and the newspaper product characteristics using QFD tables that help in prioritizing the desirable characteristics of a newspaper product based on customer needs.

4) Classification of the newspaper product characteristics, and indirectly the newspaper production.

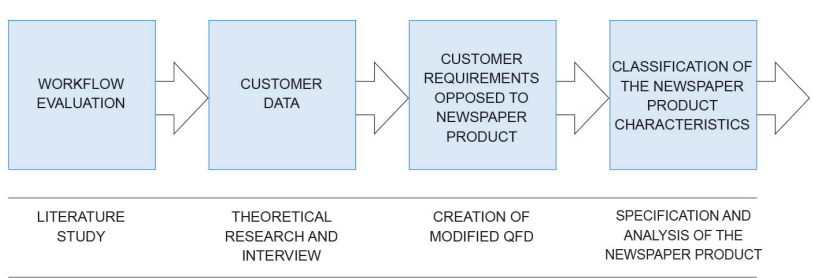

Figure 3 Process of determining specifications in the classification of the newspaper product [6]

Requests analysis helps to shift the newspaper production from product-oriented to market-oriented.

\subsection{Customer requirements and expectations for the newspaper product quality}

Newspaper products in traditional newspaper production are considered to have bad future prospects. However, newspapers have always been and still are an attractive advertising medium due to the ability to easily reach the target loyal group of readers. The relationship between newspaper products, the Internet and electronic media as a whole is considered to be more complementary than competitive. The aim of this part of the research is to identify the quality requirements arising from different systems and convert them to the properties of the newspaper product quality. The function of the advertising sector in newspaper production is twofold. Advertisements are an important part of newspaper content and in this sense advertisers have been the content providers, in addition to publishers. On the other hand, advertisers are the main source of funding for the newspapers [12]. As a buyer, the advertising sector has its own requirements for the newspaper product quality that have been studied in available publications [13, 14]. Besides visual properties, the reading experience also affects the newspaper product characteristics, therefore the high-quality product can affect the reader's impression of editorial content [15].

Table 1 Specifying requirements and characteristics for the newspaper

\begin{tabular}{|c|c|c|}
\hline $1^{\text {st }}$ Level & $2^{\text {nd }}$ Level & $3^{\text {rd }}$ Level \\
\hline $\begin{array}{l}\text { Symbolic } \\
\text { level }\end{array}$ & $\begin{array}{l}\text { Evoking } \\
\text { impressions }\end{array}$ & $\begin{array}{l}\text { - Impressions related to paper } \\
\text { - Tactile properties } \\
\text { - Sound of paper } \\
\text { - Overall visual appearance } \\
\text { - Specific colour of the paper } \\
\text { - Visual evenness }\end{array}$ \\
\hline Service & $\begin{array}{l}\text { Service from } \\
\text { paper house }\end{array}$ & $\begin{array}{l}\text { - Technical performance of the } \\
\text { printing house } \\
\text { - Flexibility in service } \\
\text { - Reliability and delivery on time }\end{array}$ \\
\hline \multirow[t]{2}{*}{$\begin{array}{l}\text { Physical } \\
\text { product }\end{array}$} & $\begin{array}{l}\text { Information } \\
\text { carrier }\end{array}$ & $\begin{array}{l}\text { - Clear and distinctive appearance } \\
\text { - Pleasant graphic design } \\
\text { - Even print quality } \\
\text { - High quality colour photography } \\
\text { - Readability }\end{array}$ \\
\hline & $\begin{array}{l}\text { Technical } \\
\text { performance }\end{array}$ & $\begin{array}{l}\text { - Little maculature } \\
\text { - No print defects } \\
\text { - No production defects } \\
\text { - Easy page turning } \\
\text { - Avoiding problems with rubbing } \\
\text { colour } \\
\text { - Good colour register } \\
\text { - Paper weight } \\
\text { - Elasticity of paper } \\
\text { - No loose pages } \\
\text { - Aligned opposite sides, Opacity }\end{array}$ \\
\hline
\end{tabular}

Tab. 1 shows the quality characteristics required for the newspaper product at the first level, divided according to the symbolic, service and physical aspects of the product. Quality characteristics are explained at the second and third levels. At the third level the newspaper product characteristics can be expressed in measurable properties using the QFD tables. The purpose of the analysis is to determine which of these lower level properties are the most important to the customer. The next step in the process of product development and production process is focused on identifying and analysing the quality of newspaper products and properties provided by the given quality level, particularly the customer expectations.

\subsection{Advertiser's requirements and expectations for the newspaper product quality}

The newspaper industry, and indirectly the newspaper production, is based on advertising revenues. The selection of the media is based on the advertising budget, communication objectives and target groups. The 
requirements of the advertising sector are strongly associated with target group, the name of newspaper publication and editorial content. The advertisement should fit in the newspaper respecting the technical specifications for advertisements [16]. It is also established that advertising is an integral part of the newspaper publication comparable to editorial content. Decisions relating to the newspaper quality are provided by publisher. The most important impacts on the quality newspaper product from the advertiser's perspective are on the print quality and all the properties it entails. The trends in publishing affect desired properties of the quality newspaper issue and therefore the advertisers are interested in other sensory properties, paper properties and even quality of the entire newspaper circulation. Budget expenditures in the advertising industry move from traditional media to the Internet. So, all interest groups are challenged to stop the decline in the number of newspapers readers [17] and thus ensure the future of newspapers and the news industry.

The specified requirements for advertisers in newspapers publications are listed in Tab. 2 .

Table 2 Specifying of the advertiser's requirements for the newspaper product quality

\begin{tabular}{|l|l|l|}
\hline \multicolumn{1}{|c|}{$1^{\text {st }}$ Level } & \multicolumn{1}{|c|}{$2^{\text {nd }}$ Level } & \multicolumn{1}{c|}{$3^{\text {rd }}$ Level } \\
\hline $\begin{array}{l}\text { Message } \\
\text { reaches its } \\
\text { target group }\end{array}$ & $\begin{array}{l}\text { Definition of } \\
\text { the target } \\
\text { group }\end{array}$ & $\begin{array}{l}\text { - Knowing the reader } \\
\text { - Knowing the reading habits }\end{array}$ \\
\cline { 2 - 3 } & $\begin{array}{l}\text { Reaching the } \\
\text { target group }\end{array}$ & $\begin{array}{l}\text { - Penetration in the target group } \\
\text { - Advertisement awakes interest }\end{array}$ \\
\hline $\begin{array}{l}\text { Advertisement } \\
\text { fits into the } \\
\text { newspaper }\end{array}$ & $\begin{array}{l}\text { Editorial } \\
\text { content and } \\
\text { advertising }\end{array}$ & $\begin{array}{l}\text { - Image is defined } \\
\text { - Constant image }\end{array}$ \\
\cline { 2 - 3 } & $\begin{array}{l}\text { Pleasant } \\
\text { appearance of } \\
\text { the newspaper } \\
\text { publication }\end{array}$ & $\begin{array}{l}\text { - Pleasant feel } \\
\text { - High-quality printing } \\
\text { - Balance between content and } \\
\text { advertisement } \\
\text { - Conveniences for advertisers in } \\
\text { advertisement layout }\end{array}$ \\
\hline $\begin{array}{l}\text { Designing } \\
\text { advertisements } \\
\text { for the } \\
\text { newspaper }\end{array}$ & $\begin{array}{l}\text { Specifications } \\
\text { for the } \\
\text { advertiser }\end{array}$ & $\begin{array}{l}\text { - No limits for advertisement } \\
\text { creation } \\
\text { - Advertisement's size versatile } \\
\text { - Advertisement's shape versatile } \\
\text { - Possibilities for special effects } \\
\text { - Possibilities of additional } \\
\text { newspaper services }\end{array}$ \\
\hline
\end{tabular}

Well-defined and established target group is the most important for advertisers. Another important requirement is how much attention is given to the advertisement and what kind of feeling it arouses. The advertiser expects the advertisement to suit the newspaper issue in design and be harmonised with the newspapers. The third requirement is related to the production, advertisement and the interaction between the advertising agency and newspaper publisher, which means that the advertisement should be designed for the newspaper issue with exact specifications for advertisers. Advertiser's requirements and expectations from the table were analysed and classified into two categories. Requirements that are clearly linked to the newspaper product quality (pleasant feel of the newspaper issue, quality printing, balance between content and advertisements, advertiser benefits concerning advertisement layout) and that might be associated with the quality (knowledge of the reader, knowledge of reading habits). The correlations between advertiser expectations and requirements and newspaper product quality are assessed and the most important properties from the advertiser perspective are shown in Tab. 3 from QFD analysis.

Table 3 The most important newspaper product properties from the advertiser's point of view

\begin{tabular}{|c|c|c|}
\hline Evoking impressions & Information carrier & Technical performance \\
\hline $\begin{array}{c}\text { Impressions related } \\
\text { to paper }(12,92 \%)\end{array}$ & $\begin{array}{c}\text { Small details visible } \\
(9,05 \%)\end{array}$ & $\begin{array}{c}\text { Easy page turning } \\
(3,87 \%)\end{array}$ \\
\hline $\begin{array}{c}\text { Tactile properties } \\
(12 \%)\end{array}$ & $\begin{array}{c}\text { Pleasant graphic } \\
\text { design }(9,05 \%)\end{array}$ & $\begin{array}{c}\text { Correct Colour register } \\
(1,29 \%)\end{array}$ \\
\hline $\begin{array}{c}\text { Sound of paper } \\
(9,05 \%)\end{array}$ & $\begin{array}{c}\text { Even print quality } \\
(7,75 \%)\end{array}$ & $\begin{array}{c}\text { No waviness in paper } \\
(1,29 \%)\end{array}$ \\
\hline $\begin{array}{c}\text { Overall visual } \\
\text { appearance } \\
(12,93 \%)\end{array}$ & - & - \\
\hline $\begin{array}{c}\text { Specific colour of } \\
\text { paper }(6,89 \%)\end{array}$ & - & - \\
\hline $\begin{array}{c}\text { Visual evenness } \\
(9,05 \%)\end{array}$ & - & - \\
\hline
\end{tabular}

Most of these properties, according to the proportion of the advertiser's requirements, belong to the category of evoking impressions in the newspaper publication as the information carrier. Furthermore, the advertiser's requirements are high in the category of quality of a newspaper as the information carrier, while the advertisers have no specific requirements in technical performance category as shown in Tab. 4. However, it can be determined that the properties in the technical performance categories, colour register and easy page turning are closely associated with the visual appearance and impression of the newspaper product. So, advertiser's expectations related to the quality of newspaper products are strongly associated with feelings either at symbolic level (e.g. sensory properties) or physical performance of the newspaper as the information carrier (e.g. visual quality)

\subsection{Publisher's requirements and expectations for the newspaper product quality}

Publishers are focused on the readers, customers, and their other important customers are advertisers. In addition to the content and the appearance, publishers offer advertisers knowledge of the target group. For publishers appearance and high print quality are very important. Publishers always look at the printed product as a whole, and do not differentiate between production process and the overall appearance of the printed product. The disadvantages mentioned in maintaining printing quality are ghosting, colour misregister, variation in print quality, problems with raw materials mainly paper and colour and waviness. Evoking impression depends on the quality appearance (design), even print quality throughout the circulation, correct and consistent colours and print, high-quality paper, a good rendering in advertisements and overall attractive appearance. Newspaper publication may differ from the competition by using different supplements, and increasing the value added. Publisher's expectations regarding printing house and the newspaper product quality are listed in Tab. 4. 
Table 4 Specifications of the publisher requirements for the newspaper product quality

\begin{tabular}{|c|c|c|}
\hline \multirow{4}{*}{$\begin{array}{l}1^{\text {st }} \text { Level } \\
\begin{array}{l}\text { Symbolic } \\
\text { level }\end{array}\end{array}$} & \multirow{2}{*}{\multicolumn{2}{|c|}{$2^{\text {nd }}$ Level }} \\
\hline & & \\
\hline & $\begin{array}{l}\text { High-quality } \\
\text { content }\end{array}$ & $\begin{array}{l}\text { Newspaper product quality } \\
\text { according to brand }\end{array}$ \\
\hline & $\begin{array}{l}\text { Newspapers' } \\
\text { pleasant } \\
\text { appearance }\end{array}$ & $\begin{array}{l}\text { - Visual quality } \\
\text { - Uniform quality } \\
\text { - Correct colours } \\
\text { - Quality paper } \\
\text { - Adhesive binding } \\
\text { - Good rendering in } \\
\text { advertisements }\end{array}$ \\
\hline Service & $\begin{array}{l}\text { Service from the } \\
\text { printing house }\end{array}$ & $\begin{array}{l}\text { - Good technical facilities } \\
\text { - Good relationships with the } \\
\text { printing house } \\
\text { - High efficiency } \\
\text { - Reliable scheduling } \\
\text { - Flexibility in service } \\
\text { - Reliability and delivery in time } \\
\text { - Meeting advertiser's technical } \\
\text { requirements }\end{array}$ \\
\hline \multirow[t]{3}{*}{$\begin{array}{l}\text { Physical } \\
\text { product }\end{array}$} & Paper properties & $\begin{array}{l}\text { - Tactile properties } \\
\text { - Visual newspaper impression } \\
\text { - Even design } \\
\text { - Distinctive shape }\end{array}$ \\
\hline & $\begin{array}{l}\text { Avoiding } \\
\text { quality } \\
\text { problems }\end{array}$ & $\begin{array}{l}\text { - No ghosting } \\
\text { - No problems with colour } \\
\text { register and rubbing colour } \\
\text { - Little variation in print quality } \\
\text { - No problems with colour and } \\
\text { paper quality }\end{array}$ \\
\hline & $\begin{array}{l}\text { Flexible } \\
\text { solutions }\end{array}$ & $\begin{array}{l}\text { - Added value with special } \\
\text { effects and finishing of the } \\
\text { newspaper product } \\
\text { - Special opportunities related to } \\
\text { advertisers } \\
\text { - Flexible printing solutions }\end{array}$ \\
\hline
\end{tabular}

Table 5 The most important newspaper product properties from the publisher's point of view

\begin{tabular}{|c|c|c|}
\hline Evoking impressions & Information carrier & $\begin{array}{c}\text { Technical } \\
\text { performance }\end{array}$ \\
\hline $\begin{array}{c}\text { Impressions related to } \\
\text { paper }(2,34 \%)\end{array}$ & $\begin{array}{c}\text { Clear and distinctive } \\
\text { appearance }(4,28 \%)\end{array}$ & $\begin{array}{c}\text { Little maculature } \\
(3,99 \%)\end{array}$ \\
\hline $\begin{array}{c}\text { Tactile properties } \\
(3,77 \%)\end{array}$ & $\begin{array}{c}\text { Pleasant graphic } \\
\text { design }(5,07 \%)\end{array}$ & $\begin{array}{c}\text { No visible printed } \\
\text { effects }(5,30 \%)\end{array}$ \\
\hline $\begin{array}{c}\text { Sound of paper } \\
(4,28 \%)\end{array}$ & $\begin{array}{c}\text { Even print quality } \\
(11,23 \%)\end{array}$ & $\begin{array}{c}\text { No production defects } \\
(4,77 \%)\end{array}$ \\
\hline $\begin{array}{c}\text { Overall visual } \\
\text { appearance } \\
(5,36 \%)\end{array}$ & $\begin{array}{c}\text { High-quality print } \\
(7,89 \%)\end{array}$ & $\begin{array}{c}\text { No problems in colour } \\
\text { register }(4,14 \%)\end{array}$ \\
\hline $\begin{array}{c}\text { Visual evenness } \\
(7,6 \%)\end{array}$ & - & - \\
\hline
\end{tabular}

Publisher's requirements from the table have also been analysed. There are requirements clearly related to the newspaper product quality (newspaper product quality harmonised with publication's brand, visual quality, uniform quality, correct colours and print, no differences between two sheets, high-quality paper, good advertisement presentation, attractiveness, no ghosting, slight variation in the print quality, no waviness) and requirements that might be related to the newspaper product quality (good relationship with printing plants, ability to meet advertiser's technical requirements, reliability and delivery on time). The correlations between the publisher's requirements for a quality newspaper product were evaluated, and the most important newspaper product properties from the publisher's point of view are identified and shown in Tab. 5 from QFD analysis.

Publishers are familiar with the quality requirements in all categories that clearly reflect the publisher's role in the newspaper product value chain as shown in Tab. 5 . So, the properties of the quality newspaper product are definitely publisher's object of interest.

\subsection{Printer's requirements and expectations for the newspaper product quality}

The employee competence is one of the main influencing parameters for the success of newspaper printing houses, but printing price is unfortunately one of the key assets of the newspaper production. It is necessary either to standardize the printing process at all levels and thereby ensure consistent print quality or offer customers a variety of solutions, for example in non-conventional forms at a reasonable price. These two options can also be combined. Tab. 6 shows the printer's requirements for the newspaper product quality. QFD analysis of the printer's requirements is shown in Tab. 7. Correlations between the printer's requirements for a quality newspaper product were evaluated, and the most important newspaper product properties from the printer's point of view are identified and shown in Tab. 8.

Table 6 Specifications of the printer's requirements for the newspaper

\begin{tabular}{|c|c|c|}
\hline $1^{\text {st }}$ Level & $2^{\text {nd }}$ Level & $3^{\text {rd }}$ Level \\
\hline $\begin{array}{l}\text { Symbolic } \\
\text { level }\end{array}$ & $\begin{array}{l}\text { Main criteria } \\
\text { in selecting } \\
\text { the paper }\end{array}$ & $\begin{array}{l}\text { - Newspaper product in line with } \\
\text { magazine's brand }\end{array}$ \\
\hline \multirow[t]{2}{*}{ Service } & $\begin{array}{l}\text { Customer } \\
\text { service }\end{array}$ & - Reliability of delivery and flexibility \\
\hline & $\begin{array}{l}\text { Supplier } \\
\text { service }\end{array}$ & $\begin{array}{l}\text { - Continuous availability of supplying } \\
\text { the quality raw materials } \\
\text { - Competitive prices of raw materials } \\
\text { - Supplier's flexibility in delivering } \\
\text { - Favourable supplier payment terms }\end{array}$ \\
\hline \multirow[t]{3}{*}{$\begin{array}{l}\text { Physical } \\
\text { product }\end{array}$} & $\begin{array}{l}\text { Production } \\
\text { control }\end{array}$ & $\begin{array}{l}\text { - Detection of errors in the newspaper } \\
\text { product }\end{array}$ \\
\hline & Quality & $\begin{array}{l}\text { - Noticeable visual quality } \\
\text { - Minimum variations } \\
\text { - Use of quality raw materials } \\
\text { - Standardized newspaper production }\end{array}$ \\
\hline & $\begin{array}{l}\text { Newspaper } \\
\text { product } \\
\text { properties }\end{array}$ & $\begin{array}{l}\text {-Favourable quality/price ratio } \\
\text { - Functionality throughout the } \\
\text { production process } \\
\text { - No sudden change in raw materials } \\
\text { - Good colour register } \\
\text { - Low ink consumption } \\
\text { - Low level of production costs } \\
\text { - No changing printing deadlines } \\
\text { - Quality paper }\end{array}$ \\
\hline
\end{tabular}


Table 7 QFD-analysis of the printing house $1^{\text {st }}$ part

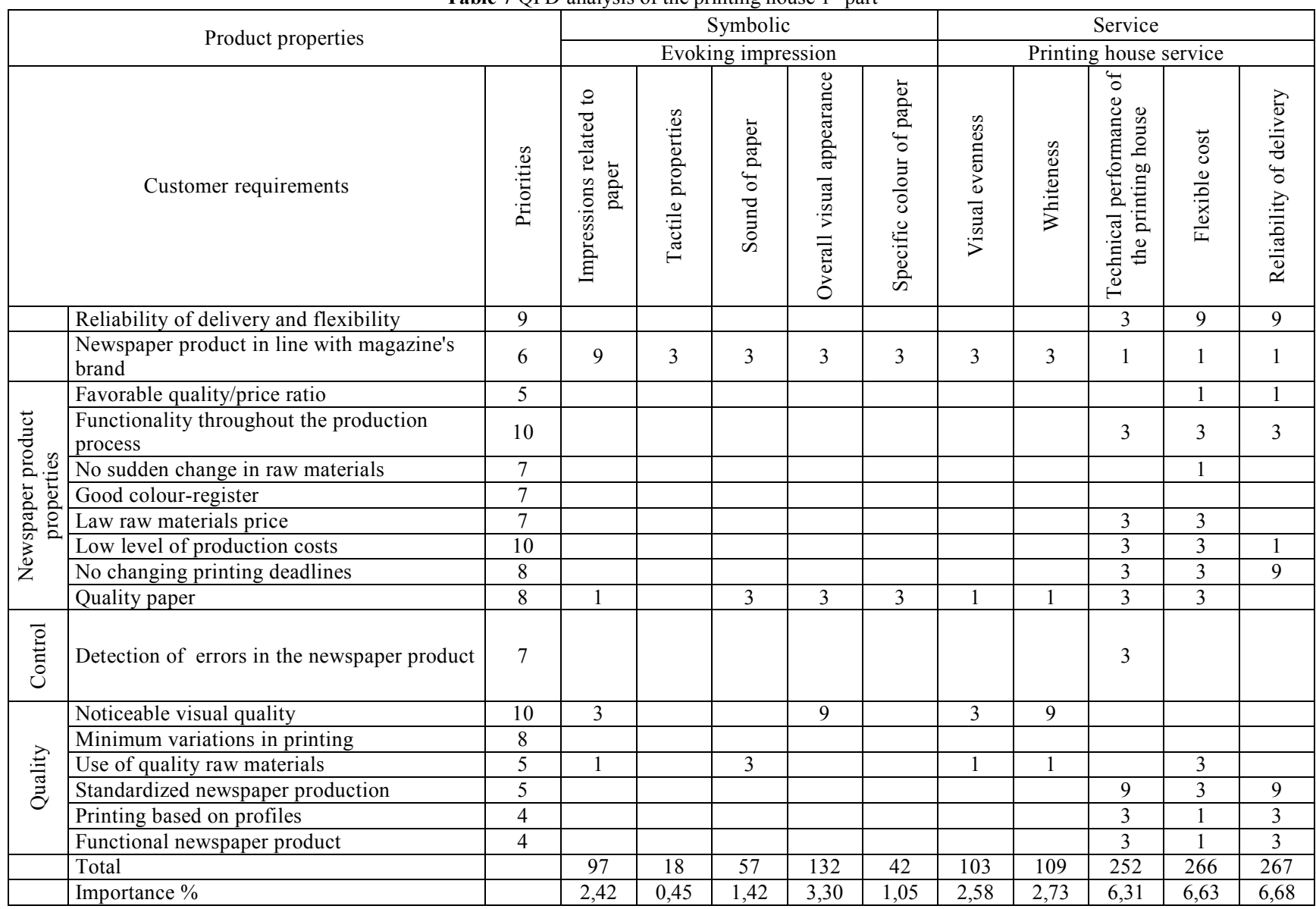

Table 7 QFD-analysis of the printing house $2^{\text {nd }}$ part

\begin{tabular}{|c|c|c|c|c|c|c|c|c|c|c|c|c|c|c|c|c|c|c|}
\hline \multirow{2}{*}{\multicolumn{3}{|c|}{ Product properties }} & \multicolumn{16}{|c|}{ Physical product } \\
\hline & & & \multicolumn{5}{|c|}{ Information carrier } & \multicolumn{11}{|c|}{ Technical properties } \\
\hline \multicolumn{2}{|r|}{ Customer requirements } & $\cdot \stackrel{\mathscr{E}}{: 0}$ & 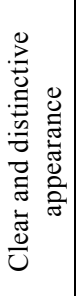 & 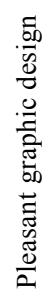 & 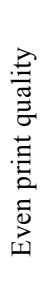 & 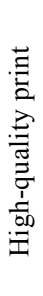 & 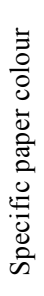 & 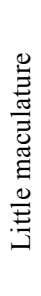 & 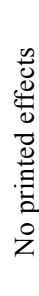 & $\begin{array}{l}0 \\
0 \\
0 \\
0 \\
0 \\
0 \\
0 \\
0 \\
0 \\
0 \\
0 \\
0 \\
0 \\
0 \\
z\end{array}$ & 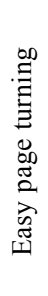 & 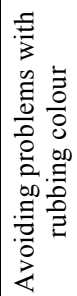 & 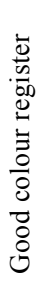 & $\begin{array}{l}\overrightarrow{0} \\
\frac{0}{00} \\
\overrightarrow{0} \\
\overrightarrow{0} \\
\text { है } \\
0\end{array}$ & 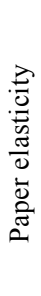 & 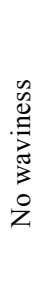 & 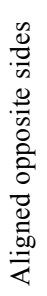 & $\begin{array}{l}\stackrel{\gtrsim}{0} \\
0 \\
0 \\
0\end{array}$ \\
\hline & $\begin{array}{l}\text { Reliability of delivery, } \\
\text { flexibility }\end{array}$ & 9 & & & & & & & 3 & & & & & & & & & \\
\hline & $\begin{array}{l}\text { Paper production line } \\
\text { with magazine's brand }\end{array}$ & 6 & 3 & 3 & 1 & 3 & 1 & & & & & & & & & 1 & 1 & \\
\hline \multirow{8}{*}{ 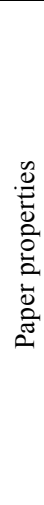 } & $\begin{array}{l}\text { Favourable } \\
\text { quality/price ratio }\end{array}$ & 5 & & & 3 & 1 & & & & 1 & & & & & & & & \\
\hline & $\begin{array}{l}\text { Functionality } \\
\text { throughout the } \\
\text { production process }\end{array}$ & 10 & & & 3 & 1 & & 9 & 9 & 9 & 3 & 3 & 3 & & & & & \\
\hline & $\begin{array}{l}\text { No sudden change in } \\
\text { raw materials }\end{array}$ & 7 & & & & & & & & & & & & & & & & \\
\hline & Good colour register & 7 & & & & & & & 3 & & & & 9 & & & & & \\
\hline & Law raw materials cost & 7 & & & & & & 1 & & & & & & & & & & \\
\hline & $\begin{array}{l}\text { Low level of } \\
\text { production costs }\end{array}$ & 10 & & & & 3 & & 9 & 9 & 9 & 1 & 1 & 3 & & & & & \\
\hline & $\begin{array}{l}\text { No changing printing } \\
\text { deadlines }\end{array}$ & 8 & & & & & & & & 1 & 3 & & & & & & & \\
\hline & Quality paper & 8 & 3 & 1 & & 1 & 9 & 1 & & 1 & 1 & & & 9 & 9 & & & 9 \\
\hline $\begin{array}{l}\overline{0} \\
\stackrel{\Xi}{0} \\
0\end{array}$ & $\begin{array}{l}\text { Detection of errors in } \\
\text { the newspaper product }\end{array}$ & 7 & & & & & & & 9 & 9 & 3 & & 3 & & & 1 & & \\
\hline
\end{tabular}




\begin{tabular}{|c|c|c|c|c|c|c|c|c|c|c|c|c|c|c|c|c|c|c|}
\hline \multirow{2}{*}{\multicolumn{3}{|c|}{ Product properties }} & \multicolumn{16}{|c|}{ Physical product } \\
\hline & & & \multicolumn{5}{|c|}{ Information carrier } & \multicolumn{11}{|c|}{ Technical properties } \\
\hline \multicolumn{2}{|c|}{ Customer requirements } & 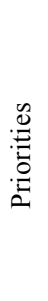 & 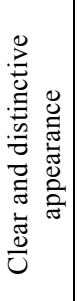 & 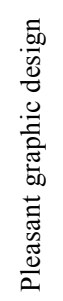 & 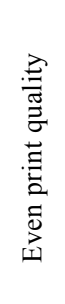 & 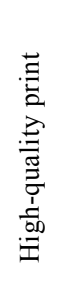 & $\begin{array}{l}\vdots \\
0 \\
0 \\
0 \\
\overline{0} \\
0 \\
0 \\
0 \\
0 \\
0.0 \\
0 \\
0 \\
\text { की }\end{array}$ & 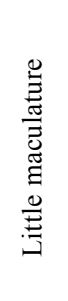 & 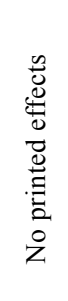 & $\begin{array}{l}0 \\
0 \\
0 \\
0 \\
0 \\
0 \\
0 \\
0 \\
0 \\
0 \\
0 \\
0 \\
0 \\
0\end{array}$ & 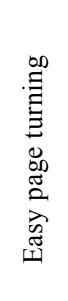 & 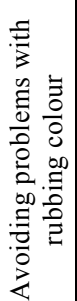 & $\begin{array}{l}\dot{0} \\
.0 \\
00 \\
0 \\
0 \\
0 \\
0 \\
0 \\
0 \\
0 \\
0 \\
0 \\
0\end{array}$ & $\begin{array}{l}\overrightarrow{ \pm} \\
\frac{00}{0} \\
0 \\
0 \\
0 \\
0 \\
0\end{array}$ & 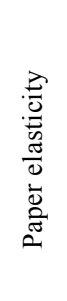 & 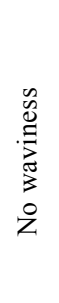 & 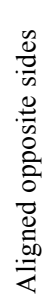 & $\begin{array}{l}\stackrel{\vec{J}}{0} \\
\stackrel{\tilde{\sigma}}{0} \\
0\end{array}$ \\
\hline \multirow{7}{*}{ 鸹 } & $\begin{array}{l}\text { Noticeable visual } \\
\text { quality }\end{array}$ & 10 & 9 & 9 & 9 & 9 & 9 & & & & & & 9 & & & & & 1 \\
\hline & Minimum variations & 8 & & & 3 & 3 & & & 3 & 3 & & & 3 & & & & & \\
\hline & $\begin{array}{l}\text { Use of quality raw } \\
\text { materials }\end{array}$ & 5 & & & & & 3 & 3 & & & & 9 & & 3 & 3 & & & 3 \\
\hline & $\begin{array}{l}\text { Standardized } \\
\text { newspaper production }\end{array}$ & 5 & & & 9 & 9 & & 3 & 3 & 9 & & & 1 & & & 1 & 1 & \\
\hline & $\begin{array}{l}\text { Functional newspaper } \\
\text { product }\end{array}$ & 4 & & & 3 & 3 & & & 3 & 9 & 3 & 3 & 3 & 3 & 3 & 3 & 3 & 3 \\
\hline & Total & & 132 & 116 & 222 & 218 & 183 & 237 & 378 & 375 & 105 & 97 & 241 & 99 & 99 & 24 & 17 & 106 \\
\hline & Importance \% & & 3,30 & 2,90 & 5,55 & 5,45 & 4,57 & 5,92 & 9,45 & 9,44 & 2,62 & 2,42 & 6,03 & 2,43 & 2,43 & 0,6 & 0,4 & 2,62 \\
\hline
\end{tabular}

Table 8 The most important newspaper product properties from the printer's point of view

\begin{tabular}{|l|l|}
\hline \multicolumn{1}{|c|}{ Evoking impressions } & \multicolumn{1}{c|}{ Service from the printing house } \\
\hline $\begin{array}{l}\text { Impressions related to paper } \\
(2,91 \%)\end{array}$ & $\begin{array}{l}\text { Technical performance of the printing } \\
\text { house }(6,47 \%)\end{array}$ \\
\hline $\begin{array}{l}\text { Overall visual appearance } \\
(3,40 \%)\end{array}$ & Flexible service $(6,83 \%)$ \\
\hline & Reliability, delivery on time $(6,86 \%)$ \\
\hline & Clear, distinctive appearance $(3,30 \%)$ \\
\hline & Even print quality $(5,55 \%)$ \\
\hline & High print quality $(5,45 \%)$ \\
\hline & Little maculature $(5,92 \%)$ \\
\hline & No print defects $(9,45 \%)$ \\
\hline & No production defects $(9,55 \%)$ \\
\hline & Good colour register $(6,03 \%)$ \\
\hline
\end{tabular}

Printing house has a high level of expectations in terms of technical properties in order to meet the quality newspaper product requirements. Primary technical properties of the quality newspaper product are production with no print defects $(9,45 \%)$ and no production defects $(9,55 \%)$ and a good colour-register $(6,03 \%)$ and little maculature $(5,92 \%)$. The need for minimal variations in high-quality collides with bad properties of the newspaper products. Printer's expectations for the quality of the newspaper product as the information carrier with balanced and high quality printing (5,55 and 5,45\%) was rated very highly. Besides these analyses it is essential to maintain low production costs for maintaining the newspaper products quality.

\section{Conclusion}

This paper analysed the requirements of all value chain participants for improving the newspaper product quality, their interrelations to meet customer's main requirements and expectations. Each QFD table showed the level or percentage of importance according to the newspaper product quality. Respecting the order of importance of certain value chain participants' requirements, the rank order of the newspaper product characteristics and production processes has been created. Thus the primary objective of this study was achieved, the methodology of analysis of the requirements from the customer's perspective was developed to be used in the process of developing high-quality newspaper products meaning that quality area has been created between the customer and the newspaper product to the printing house. Obtained study results can be generalized, which means that hard data will be obtained for the particular newspaper product. Doubts about the importance of certain properties in certain phases of QFD in the value chain should be minimized, and the focus should be put on the parameters affecting the success and the final product quality. Not only had it become clear which properties a newspaper product should have, but also the requirements a printing house should meet and the intensity needed to achieve this goal. Application of the modified QFD methodology will also help increase the competitiveness in creating the existing newspaper products and will be an indispensable tool in the quality management when creating a new product range which is a clear answer to the question of survival of the newspaper.

\section{References}

[1] WAN IFRA Shaping the future of the newspaper. // A world assosiation of newspapers and news publishers. 9, 2(2010), pp. 9-18.

[2] Milčić, D.; Donevski, D.; Banić, D. Integrirani sustavi upravljanja u grafičkoj industriji. // Poslovna izvrsnost. 2, 1(2008), pp. 63-71.

[3] Löfgren, K. Important Quality Characteristics in the Production of Release Liners, Master's Thesis : University of Technology, Helsinki, 2001.

[4] Jernström, E. Assessing the technical competitiveness of printing paper, Espoo: VTT Technical Research Centre of Finland, Helsinki, 2000.

[5] Gruner, K. E.; Homburg, C. Does customer interaction enhance new product success? // Journal of Business Research. 49 (2000), pp. 1-14. DOI: 10.1016/S01482963(99)00013-2

[6] Aikala, M. Quality space of the magazine - A methodological approach to customer requirements as a 
driver of product development, Dissertation for the degree of Doctor of Science in Technology : Faculty of Chemistry and Materials Science, Helsinki, 2009.

[7] Charnock, J. What do book manufacturers need to do deliver what publishers are looking for https:// ricoheuropebusinessdriver.wordpress.com (25.08.2015)

[8] Grunert, K. G.; Grunert, S. C. Measuring subjective meaning structures by the laddering method: theoretical considerations and methodological problems // International Journal of Research in Marketing. 12(1995), pp. 209-225. DOI: 10.1016/0167-8116(95)00022-T

[9] McCann, R. Magazine trends, advertising, and innovation to address the needs of this market. // Proceedings of TAPPI Coating and Graphic Arts Conference / Baltimore, 2004, pp. $98-112$

[10] Iltanen, S. Constructing the image of a user through design. // Proceedings of British Society for Gerontology Conference / Keele, 2005, pp. 189-198.

[11] Ulrich, K. T.; Eppinger, S. D. Product Design and Development. McGraw-Hill, New York, 2000.

[12] Henry, G.; Hawkins, E. Newspaper Advertising: Being a Series of Talks on the Value And Use of this Greatest of all Local Advertising Mediums - the Newspaper with Reproductions. Palala Press, London, 2015.

[13] Rowell, G. P. Newspaper Advertising. Nabu Press, Charleston, 2012.

[14] Rogers, J. Building Newspaper Advertising: Selling the ByProduct of the Newspaper, Printed Salesmanship; Management and Organization of the Selling Force-Development of New Lines of Business. Ulan Press, London, 2012.

[15] Anon, A. Growth rate of U. S. Newsprint Consumption and Real GDP. Facts about Newspaper. 2004. http://www.naa.org/info/facts04/newsprint-growth.html (29.12.2008)

[16] Kilman, L. World Press Trends: Newspaper Revenues Shift To New Sources. 2015. http://www.wan-ifra.org/wpt. (01.06.2015)

[17] Lyttle, C. Will newspapers become extinct?: With the growth and development of digital media news what strategies should newspapers use to retain readership and loyalty to their printed and online brands? Kindle Edition: Caroline Lyttle, 2015.

\section{Authors' addresses}

prof. dr. sc. Diana Milčić, dipl. ing. stroj.

University of Zagreb, Faculty of Graphic Arts

Getaldićeva 2, 10000 Zagreb, Croatia

E-mail: dmilcic@grf.hr

Jakov Borković, dipl. ing. graf.

Alterpress d.o.o.

Lička 33, 10000 Zagreb, Croatia

E-mail: jakov.borkovic@gmail.com

prof. dr. sc. Adisa Vučina, dipl. ing. stroj.

Faculty of Mechanical Engineering and Computing,

University of Mostar

Matice hrvatske bb, 88000 Mostar

Bosnia and Herzegovina

E-mail: adisa@sve-mo.ba 